\title{
A CROSS SECTIONAL STUDY ON DOMESTIC ACCIDENTS AMONG THE RESIDENTS OF RURAL FIELD PRACTICE AREA OF ANNAPOORNA MEDICAL COLLEGE, SALEM, TAMILNADU
}

\author{
Mohammed Ibrahim R ${ }^{1}$, Priyadarsini S.P2
}

${ }^{1}$ Assistant Professor, Department of Community Medicine, Annapoorana Medical College and Hospitals, Salem. ${ }^{2}$ Assistant Professor, Department of Community Medicine, Annapoorana Medical College and Hospitals, Salem.

\section{ABSTRACT}

\section{BACKGROUND}

Domestic accidents are worldwide public health problems. The consequences of a domestic accident may prove disastrous, as it may result in disability and loss of productivity. In this context, the present study was carried out to characterize the occurrence of domestic accidents in the selected rural community.

\section{AIMS}

To study the prevalence of domestic accidents in the selected rural population and its association with various socioepidemiological factors.

\section{SETTINGS AND DESIGN}

Community-based cross-sectional study.

\section{MATERIALS AND METHODS}

Complete information from 372 households consisting of 1497 individuals was collected through semi-structured questionnaire. A case was considered as domestic accident when any of these individuals had met with an accident inside the house or in the immediate surroundings of the house during the last 6 months from the date of survey. The collected data were tabulated and analysed using SPSS software version 21.

\section{STATISTICAL ANALYSIS USED}

Frequency, proportions and Chi-square test.

\section{RESULTS}

The prevalence of domestic accidents was found to be $4.6 \%$. The most common accidents reported was falls (65\%). Other accidents noted were burns, scalds, cuts and lacerations and accidental poisoning. Accidents were reported in significantly higher proportion in 50 and above age groups and in females. Higher proportion of accidents occurred during the morning and evening hours.

\section{CONCLUSIONS}

The present study was an attempt to highlight the epidemiological features of domestic accidents in the study area. It also tried to address issues in prevention of domestic accidents. Eg: Health Education in local language regarding prevention of accidents and to prevent accidental falls.

\section{KEYWORDS}

Domestic Accidents, Cross Sectional Study and Rural Population.

HOW TO CITE THIS ARTICLE: Ibrahim MR, Priyadarsini SP. A cross sectional study on domestic accidents among the residents of rural field practice area of Annapoorna Medical College, Salem, Tamilnadu. J. Evolution Med. Dent. Sci. 2016;5(31):

1609-1612, DOI: $10.14260 / \mathrm{jemds} / 2016 / 379$

\section{INTRODUCTION}

Domestic accidents are worldwide public health problems. Accidents can take place in a wide variety of environments and there is a possibility of accidents in every sphere of human life: at home, at play and at work.(1)

Financial or Other, Competing Interest: None.

Submission 17-02-2016, Peer Review 15-03-2016,

Acceptance 19-03-2016, Published 15-04-2016.

Corresponding Author:

Dr. Mohammed Ibrahim R,

A22, Staff Quarters,

Annapoorana Medical College and Hospitals,

Veerapandi,

Salem-636308

E-mail: ibimmc.2000@gmail.com

DOI: $10.14260 /$ jemds $/ 2016 / 379$
The problem is more grave in developing countries, particularly in rural areas, shanty towns or informal dwellings. $(2,3)$

Every domestic accident brings a varying measure of distress to the victim as well as the family members. The consequences may be disastrous, both for the individual and the society when the accident results in permanent disability, as the victim loses his earning capacity and may not be able to enjoy a normal active life. Children in particular are more vulnerable to domestic accidents, resulting in disability and loss of future productivity. $(4,5)$

These accidents have not so far been recognized to the same extent as traffic and work-related injuries, largely because they have not been effectively counted. 
Since prevalence studies on domestic accidents in rural area were not widely available particularly in rural Tamilnadu, we have preceded this study to find out the prevalence of domestic accidents and their association with various sociodemographic factors, so that the public health planners can identify potential socio-environmental factors to reduce these accidents in the selected rural area.

\section{METHODOLOGY}

The present cross sectional study was conducted in three randomly selected villages namely Perusanatham, Elampillai and Magudanchavadi which is the rural field practice area of Annapoorna Medical College and Hospital, Salem District, Tamilnadu from December 2014 to February 2015. There were 10 villages served under the field practice area of Annapoorana Medical College. There were total of 450 households in these three villages. A household included all the persons who occupy a housing unit or a dwelling unit.

With reference to the study.(6) conducted in South India, the prevalence of domestic accidents was taken as $9.6 \%$ and the sample size arrived at 1128 with $20 \%$ allowable error with $20 \%$ non-response rates. We have covered the sample size of 1497 in 372 households in the selected three villages during the study duration. Written consent was taken from the head of the family/adult person whom we have interviewed after explaining the objectives and procedure of the study.

A semi-structured questionnaire was used to collect the data on the background information, type and time of accident, morbidity due to that in the last six months among 372 households by interviewing the available eldest adult belonging to the particular household. Approval from the Institutional Ethics Committee was taken prior to the study initiation.

Domestic accident was considered when any of these individuals had met with an accident inside the house or in the immediate surroundings of the house during the last 6 months from the date of survey. Overcrowding was considered when number of persons per room exceeded the accepted standards. $(7,8)$

The collected data were tabulated and analysed in terms of frequencies and proportions. To study the relationship between the various socio-demographic factors with domestic accidents, Chi-square test was applied. P-value less than 0.05 was considered significant.

\section{RESULTS}

\section{Socio-demographic Characteristics of the Study Population}

This present study was done among 372 households comprising 1497 population, among which males and females comprise $780(52 \%)$ and 717 (48\%) respectively. Majority of the respondents were illiterates 411 (27.5\%). The main occupation of the surveyed villages were agriculture and weaving. The annual income for majority of the families were >Rs. 1 lakh 188 (32.7\%) and >Rs. 64908 (20.5\%). Around 52\% (192) of the respondents were living in semi-pucca houses.

\section{Determinants Influencing Domestic Accidents}

Prevalence of domestic accidents among the surveyed population found to be $4.6 \%$ (69). Majority of the domestic accidents include falls 45 (65\%) and cut injury from sharps 18 (26.1\%), cuts and burns 12 (17.4\%) (Table 2).

The most common age in which the accidents encountered were 50 and above was 20 (29\%), followed by 31-40 years was $12(17 \%)$ (Table 3$)$. The reported accidents were more common among females 41 (59\%) and it is found to be statistically not significant $p=>0.05$ (Table 3 ). Regarding occupation reported accidents was high among the unskilled workers, which was found to be statistically significant $(p<0.0002)$ (Table 3). The place of occurrence of accidents were mainly space around home 39 (56\%) and bathroom 19 (28\%) (Table 4). Majority of the incidents took place in the morning 29 (42\%) than evening 23 (33\%) (Table 4).

\section{DISCUSSION}

A study done by Ramesh Masthi et al.(6) found that the prevalence of domestic accidents in the rural community was found to be $9.6 \%$ and more among females compared with males. Similar findings has also been noted in the present study that the prevalence was $4.6 \%$ (In 372 households) and females encountered many number of accidents 41 (59\%) than males 28 (41\%), which was found to be statistically not significant $(\mathrm{p}>0.05)$. Similar observations has been noted in various studies done by Dinesh J Bhanderi.(9) Vani Madhavi Kommula.(10) and Devroey et al.(11) Chaurasia and Shukul also reported a higher incidence of domestic accidents in females in their study.(12) Neghab et al. also reported similar gender difference in their study. (13)

The most common accident reported in the present study was falls, i.e. $65.0 \%$. This category included fall on floor, slipping in bathroom and fall from stairs. Other accidents noted were burns, electrocution, injuries from sharps and accidental poisoning. Similar observations has also been noted by Dinesh J Bhanderi.(9), falls were around $71.0 \%$ in the rural Karnataka. Many other studies carried out in India and abroad also report falls as the commonest mode of injury. $(4,5,14,15)$ In contrast to this a study done by Vani Madhavi Kommula.(10) reported that most common accidents reported were injuries from sharp or pointed instruments (32.2\%) followed by falls (26.9\%). Chaurasia and Shukul.(12) observed a higher proportion of burns and scalds in their study. Neghab et al.(13) reported that burns and sharp-object injuries were the most common types of domestic accidents. In accidental poisoning group, one case of cleansing acid consumption was reported. Contrast to this Vani Madhavi Kommula.(10) noted that 5 children with kerosene poisoning and 2 with shampoo poisoning.

Analysing further the occurrence of accidents among the individuals in the age group of 50 and above it was found to be marginally higher, though not significant compared to other age groups [Table 3].

Considering the time of accident, 29 (42\%) accidents occurred during the morning hours, 23 (33\%) in the evening and $3(5 \%)$ during the night. So, a higher proportion of accidents occurred during the morning and evening hours (Table 4). As far as treatment-seeking pattern is concerned, majority of the respondents prefer Govt. and Private Hospitals $42(61 \%)$ followed by hospitals alone 22 (32\%) (Table 5). No death related to domestic accident was reported in the present study. Though Neghab et al. reported mortality rate due to domestic accidents was quite high, i.e. $1.3 \%$ in their study.[13] 


\section{CONCLUSION}

The present study was an attempt to highlight the epidemiological features of domestic accidents in the study area. It also tried to address issues in prevention of domestic accidents. Eg. Health Education in local language regarding prevention of accidents and to prevent accidental falls. Thus, domestic accident cases are a special group in themselves reflecting more clearly than any other, the character and way of living of people. A broader study involving the whole rural population may provide a clearer picture of the epidemiology of domestic accidents in our country.

\section{Limitations}

The results of the study cannot be generalised since the sampling was a convenient sampling. All the victims who have met with domestic accidents could not be interviewed personally since some of them were not available during the interview. Some degree of recall bias, especially with reference to trivial injuries could not be ruled out.

\section{Recommendations}

We are beginning to realize that domestic accidents is a public health problem of great magnitude of all ages. The prevention of domestic accidents can be attempted locally through the individual and the family by creating awareness about the occurrence of accidents and the ways to prevent them.

\begin{tabular}{|c|c|c|}
\hline Age in Years & Frequency & Percentage (\%) \\
\hline $0-10$ & 169 & 12 \\
\hline $11-20$ & 258 & 17 \\
\hline $21-30$ & 320 & 22 \\
\hline $31-40$ & 247 & 16 \\
\hline $41-50$ & 230 & 15 \\
\hline Above 50 & 273 & 18 \\
\hline \multicolumn{3}{|c|}{ Educational Status } \\
\hline Illiterate & 411 & 27.5 \\
\hline Primary & 345 & 23 \\
\hline Middle & 191 & 12.8 \\
\hline High School & 256 & 17.1 \\
\hline Higher Secondary & 87 & 5.8 \\
\hline Degree/Diploma & 207 & 13.8 \\
\hline \multicolumn{3}{|c|}{ Occupation } \\
\hline Unemployed & 171 & 11.4 \\
\hline Unskilled & 130 & 8.7 \\
\hline Semiskilled & 636 & 42.5 \\
\hline Skilled & 114 & 7.6 \\
\hline Students & 446 & 29.8 \\
\hline \multicolumn{3}{|c|}{$\begin{array}{c}\text { Table 1: Demographic Profile of the Respondents } \\
\text { in the Surveyed Population }\end{array}$} \\
\hline
\end{tabular}

Mean age of the respondents was 31 years.

\begin{tabular}{|c|c|c|}
\hline $\begin{array}{c}\text { Type of Domestic } \\
\text { Accidents }\end{array}$ & Frequency & Percentage \\
\hline Falls & 45 & 65.2 \\
\hline Burns & 4 & 5.8 \\
\hline Cut injury form sharps & 18 & 26.1 \\
\hline Cuts and burns & 12 & 17.4 \\
\hline Cuts and falls & 8 & 11.6 \\
\hline Drowning & 1 & 1.5 \\
\hline Poisoning & 1 & 1.5 \\
\hline Table 2: Types of Domestic Accidents Reported \\
from the Surveyed Population \\
\hline
\end{tabular}

\begin{tabular}{|c|c|c|c|c|}
\hline $\begin{array}{c}\text { Age } \\
\text { in Years }\end{array}$ & $\begin{array}{c}\text { Study } \\
\text { Populat } \\
\text { ion } \\
\mathrm{N}=1497\end{array}$ & $\begin{array}{l}\text { Accidents } \\
\mathrm{N}=69\end{array}$ & $\begin{array}{c}\text { No. } \\
\text { Accidents } \\
\mathrm{N}=1428\end{array}$ & $\begin{array}{l}\text { Accident } \\
\text { Rate (\%) }\end{array}$ \\
\hline Male & 780 & 28 & 752 & 3.59 \\
\hline Female & 717 & 41 & 676 & 5.72 \\
\hline \multicolumn{5}{|c|}{$\mathrm{X} 2=3.81 \mathrm{P}>0.05$} \\
\hline $0-10$ yrs. & 169 & 7 & 162 & 4.14 \\
\hline $11-20$ yrs. & 258 & 10 & 248 & 3.87 \\
\hline $21-30$ yrs. & 320 & 10 & 310 & 3.13 \\
\hline $31-40$ yrs. & 247 & 12 & 235 & 4.86 \\
\hline $41-50$ yrs. & 230 & 10 & 220 & 4.35 \\
\hline $\begin{array}{l}50 \text { yrs. and } \\
\text { above }\end{array}$ & 273 & 20 & 253 & 7.33 \\
\hline \multicolumn{5}{|c|}{$\mathrm{X} 2=6.66 \mathrm{P}$ value $>0.05$} \\
\hline \multicolumn{5}{|c|}{ Educational Status } \\
\hline Illiterate & 411 & 22 & 389 & 5.35 \\
\hline Primary & 345 & 19 & 326 & 5.51 \\
\hline $\begin{array}{c}\text { Up to } \\
\text { secondary }\end{array}$ & 447 & 21 & 426 & 4.70 \\
\hline $\begin{array}{c}\text { Higher } \\
\text { secondary }\end{array}$ & 87 & 2 & 85 & 2.30 \\
\hline $\begin{array}{l}\text { Degree/ } \\
\text { Diploma }\end{array}$ & 207 & 5 & 202 & 2.42 \\
\hline \multicolumn{5}{|c|}{$\mathrm{X} 2=4.477 \mathrm{P}$ value $=0.2142$} \\
\hline \multicolumn{5}{|c|}{ Occupation } \\
\hline Unemployed & 171 & 4 & 167 & 2.34 \\
\hline Unskilled & 130 & 25 & 105 & 19.23 \\
\hline Semiskilled & 636 & 28 & 608 & 4.40 \\
\hline Skilled & 114 & 4 & 110 & 3.51 \\
\hline Students & 446 & 8 & 438 & 1.79 \\
\hline \multicolumn{5}{|c|}{$\mathrm{X} 2=73.63 \mathrm{P}$ value $<0.0001$} \\
\hline $\begin{array}{r}\text { Table 3: Distri } \\
\text { the }\end{array}$ & $\begin{array}{l}\text { tion of Var } \\
\text { spondents }\end{array}$ & ous Socio-De & $\begin{array}{l}\text { nographic } \\
\text { Accidents }\end{array}$ & actors of \\
\hline
\end{tabular}

\begin{tabular}{|c|c|c|}
\hline $\begin{array}{c}\text { Socio- } \\
\text { demographic } \\
\text { Factors }\end{array}$ & Frequency & Percentage \\
\hline \multicolumn{3}{|c|}{ Type of Family } \\
\hline Nuclear & 29 & 42 \\
\hline Joint & 37 & 54 \\
\hline Three generation & 3 & 4 \\
\hline \multicolumn{3}{|c|}{ Place of Injury } \\
\hline Bathroom & 19 & 28 \\
\hline Kitchen & 7 & 10 \\
\hline Staircase & 4 & 56 \\
\hline $\begin{array}{c}\text { Space around } \\
\text { home }\end{array}$ & 39 & 49 \\
\hline \multicolumn{3}{|c|}{ Time of Injury } \\
\hline Morning & 34 & 13 \\
\hline Afternoon & 9 & 53 \\
\hline Evening & 23 & 5 \\
\hline Night & 3 \\
\hline $\begin{array}{c}\text { Table 4: Distribution of Respondents with } \\
\text { various Socio-Demographic Factors }\end{array}$
\end{tabular}

\begin{tabular}{|c|c|c|}
\hline Place of Treatment & Frequency & Percentage \\
\hline GH and Private & 42 & 61 \\
\hline Private hospital alone & 22 & 32 \\
\hline PHC & 8 & 12 \\
\hline First aid at home & 4 & 6 \\
\hline \multicolumn{2}{|c|}{ Table 5: Distribution of the Respondents with } \\
their Health Seeking Behaviour \\
\hline
\end{tabular}




\section{ACKNOWLEDGEMENT}

We acknowledge the services provided by the medical officers and medical-social workers posted at RHTC, Magudanchavadi, during the study period.

\section{REFERENCES}

1. WHO-EURO. Review of evidence on housing and health: background document, fourth ministerial conference on environment and health Budapest, Hungary, 2004;2325.

2. Galal S. Working with families to reduce the risk of home accidents in children. East Mediterr Health J 1999;5(3):572-82.

3. Stalin P, Senthilvel V, Kanimozhy K, et al. Burden, distribution and impact of domestic accidents in a semiurban area of coastal Tamil Nadu, India. Int J Inj Contr Saf Promot 2015;22(1):11-5.

4. Paes CE, Gaspar VL. Unintentional injuries in the home environment: home safety. J Pediatr (Rio J) 2005;81(5):S146-54

5. Zafar Fatmi, Wilbur C Hadden, Junaid A Razzak, et al. Incidence, patterns and severity of reported unintentional injuries in Pakistan for persons five years and older: results of the national health survey of Pakistan 1990-94. BMC Public Health 2007;7:152.

6. Ramesh Masthi NR, Kishore SG, Gangaboriah. Prevalence of domestic accidents in the rural field practice area of a medical college in Bangalore, Karnataka. Indian J Public Health 2012;56(3):235-7.
7. Park K. Textbook of preventive and social medicine. Jabalpur: Banarasidas Bhanot Publishers; Environment and health, 2015;22nd ed:p 752.

8. Mittal BN, Indrayan A, Sengupta $\mathrm{RK}$, et al. Epidemiological triad in domestic accidents. Indian J Med Res 1975;63(9):1344-51.

9. Bhanderi DJ, Choudhary S. A study of occurrence of domestic accidents in semi-urban community. Indian J Community Med 2008;33(2):104-6.

10. Vani Madhavi Kommula, Kusneniwar GN. A study of domestic accidents in the rural area of South India. Int J Curr Microbiol App Sci 2015;4(4):764-7.

11. Devroey D, Van Casteren V. The incidence of home accidents is going down in Belgium. Int J Inj Contr Saf Promot 2006;13(3):200-2.

12. Chaurasia R, Shukul M. Home-is it the safest place? J Soc Sci 2006;12:171-6.

13. Neghab M, Rajaei FM, Habibi M, et al. Home accidents in rural and urban areas of shiraz, 2000-02. East Mediterr Health J 2006;12(6):824-33.

14. Amuyunzu MK, Muniu E, Mwaura LW, et al. Aetiology \& implications of domestic injuries in the elderly. East Afr Med J 1997;74(10):614-17.

15. Mukhopadhya J. A study of domestic accidents in an air force community. Medical Journal Armed Forces India 1998;54(3):219-21. 